\title{
Sea Mayweed Tripleurospermum maritimum and Scentless Mayweed $T$. inodorum (Asteraceae) intermediates in Orkney.
}

\author{
John Crossley $^{1 *}$, Christopher A. Skilbeck ${ }^{2}$ \\ ${ }^{1}$ Orkney, U.K., ${ }^{2}$ Natural History Museum, London, U.K.
}

*Corresponding author: John Crossley: flawsjohn@gmail.com

This pdf constitutes the Version of Record published on $16^{\text {th }}$ September 2021

\begin{abstract}
This article describes a study of Tripleurospermum maritimum (L.) W.D.J. Koch and T. inodorum (L.) Sch. Bip. (Asteraceae) in the Orkney Islands (V.c.111), the results of which suggest that intermediates between these taxa may be rather common, and that $T$. maritimum subsp. nigriceps and subsp. maritimum are both involved, the former more frequently. Obviously this results in a complex taxonomic situation, evidently not confined to Orkney in the far north. Key identifying characters of the taxa are systematically examined and guidance offered on determining hybrids using a population level approach. The taxonomic complexities of these northern populations are discussed, with regard in particular to the identity of $T$. inodorum occurring there and the place of T. maritimum subsp. nigrescens in the forms and subspecies of $T$. maritimum found in the north Atlantic region.
\end{abstract}

Keywords: nigriceps, phaeocephalum; achene; oil-gland; rib; phyllary

\section{Introduction}

Tripleurospermum maritimum (L.) W.D.J. Koch (Sea Mayweed) is abundant around Orkney (v.c.111) shores, and similar-looking plants - robust, fleshy-leaved and often somewhat woody at the base - are common inland as weeds of arable crops and in disturbed habitats including road verges, car parking places, industrial estates, waste dumps, farmyards and neglected gardens. Very few of these inland plants seem to be convincing examples of $T$. inodorum (L.) Sch. Bip. (Scentless Mayweed). One of the current authors (JC) carried out a comparative study of these inland plants and coastal ones, using achene and vegetative characters, in 2013. The results were puzzling. The samples combined the characters of $T$. maritimum subsp. maritimum, T. maritimum subsp. nigriceps P.D. Sell and T. inodorum in so many ways that it was difficult to sort them into discrete groups. However, the results suggested that the two subspecies of $T$. maritimum were present, that intermediates between these and $T$. inodorum were frequent, and that $T$. inodorum itself was rather rare. Plants from inland habitats were especially varied. There the matter rested until a publication of a paper (Skilbeck et al., 2019) on British and Irish Mayweeds and Chamomiles, which elucidated identification of the various taxa primarily using achene morphology. With regard to Tripleurospermum, the authors concluded on the basis of the herbarium material available to them that the vast majority of specimens (from all parts of 
the British Isles) could be determined clearly as either T. maritimum or T. inodorum but a small minority of specimens in which the distinctions were 'blurred' were putative hybrids. This minority had mixed and conflicting achene characters. Some of these putative hybrids were from Orkney and Shetland (v.c.112). Indeed, several specimens from these islands were unusual in other ways and the authors discussed probable reasons for this, including introgression between the two species, the presence of the northern T. maritimum subsp. nigriceps in the area and the possibility of introgression from the Arctic subspecies $T$. maritimum subsp. phaeocephalum (Ruprecht) Hämet-Ahti. JC's earlier study suggested that there was much more to be discovered about this cryptic group and a further investigation was then conducted by the current authors, using the 2013 samples and more collected in 2019. Further observations were made in 2020 in order to better understand the morphology of subspecies occurring in the area.

\section{Characteristics of the taxa}

Both T. maritimum and T. inodorum have attracted the attention of many taxonomists and were intensively studied by Kay $(1969,1972,1994)$ in particular. Differences between the achenes of the two species (see Fig. 1) have been used for many years as a reliable and fairly easily observable means of distinguishing between them. To summarise, those of $T$. inodorum have more or less round oil sacs on the abaxial side and widely separated ribs on the adaxial side; both these characters appear to be constant. Those of T. maritimum usually have oblong or elongated oil sacs on the abaxial side (though exceptionally they may be shorter), and larger, more or less unseparated ribs on the adaxial side; the latter character appears to be constant. Much more, and necessary, detail has been provided in Kay (1972), standard Floras and, notably, the recent article by Skilbeck et al. (2019). The achenes of hybrids are generally considered to be 'intermediate' between those of the two parental species (Stace, 2019; Stace et al. 2015). Kay (1972) discussed intermediates between the two species, concluding that introgression from $T$. inodorum into $T$. maritimum could occur in favourable circumstances where the two species meet close to the seashore. Regarding these intermediates, it is noteworthy that he stated "Oil-gland shape and rib inflation were weakly linked in 'introgressed' populations", suggesting that inconsistencies between rib thickness and oil-gland shape may be indicative of hybridisation, although he also suggested giving precedence to rib thickness (and hence probable $T$. maritimum identity) when rib-development and gland shape are inconsistent. Kay (1972) also considered achenes from plants with fleshy leaves and other T. maritimum characters such as short little-branched stems, with more weakly developed ribs and less strongly elongated oil-glands as populations showing probable introgression from $T$. inodorum. He also conducted breeding experiments, generating hybrids, but we have been unable to trace any of his original material, and detailed descriptions of hybrid characteristics and how these characters segregate were not published by Kay.

In addition to achene morphology, vegetative characters distinguishing the species comprise fleshiness of the leaves, shape of the phyllaries and width of phyllary margins. Differences in phyllaries have also been key to describing subspecies of T. maritimum, in our case the widespread subsp. maritimum occurring on the coasts of the British Isles, North Sea and the Baltic, and the more northern subspecies and forms including subsp. nigriceps. 

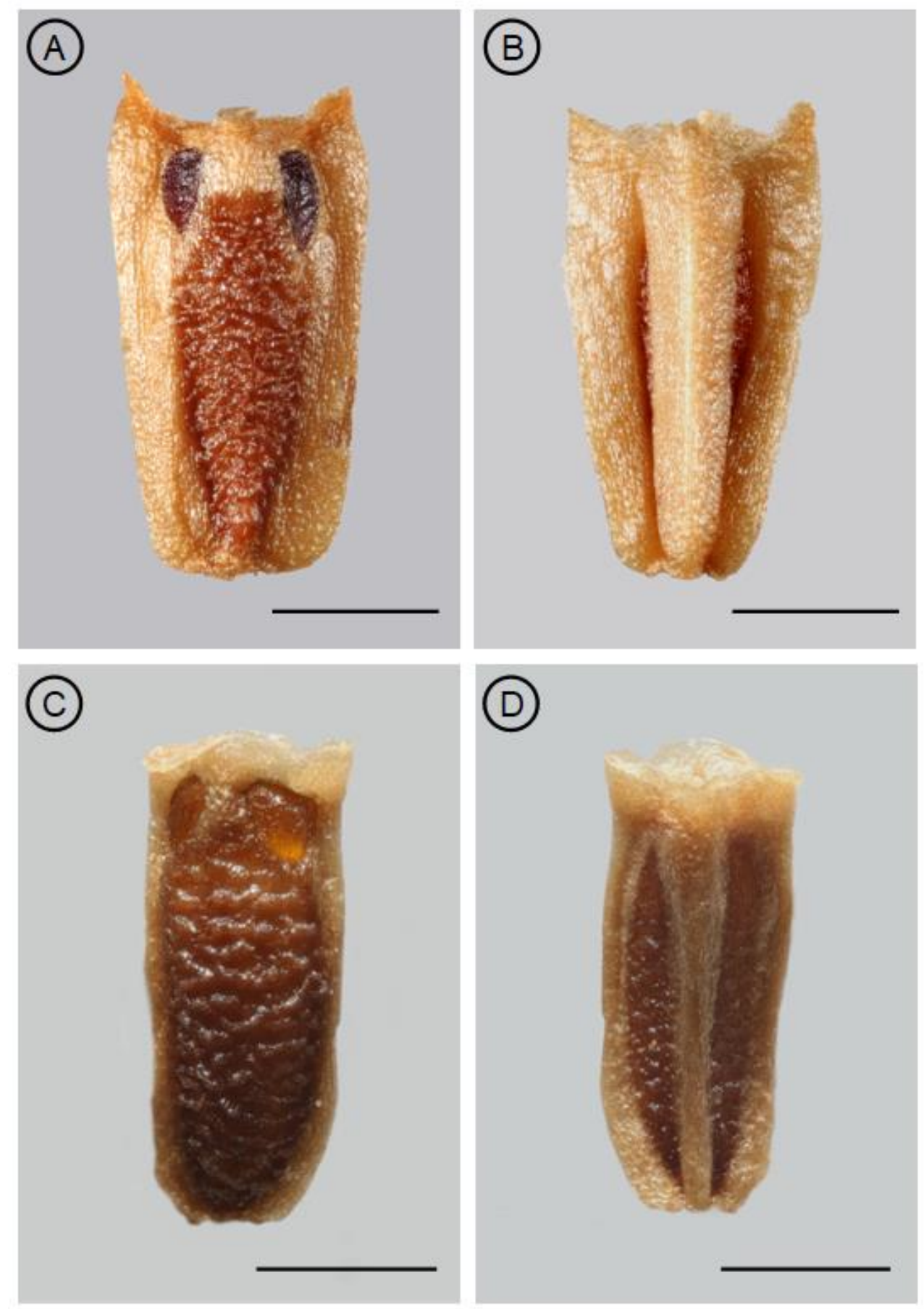

Figure 1. 'Typical' achenes of Tripleurospermum. A, B: T. maritimum (subsp. maritimum), v.C.2 in abaxial (A) and adaxial (B) view. C, D: T. inodorum from near Merton Farm, v.c.15, in abaxial (C) and adaxial (D) view. Scale bars $=0.5 \mathrm{~mm}$. Note that the pair of abaxial oil sacs (A) are more than 1.5 times as long as wide in $T$. maritimum (and sometimes much more elongated than shown here) and the three adaxial ribs (B) are much thickened with spongy tissue to act as flotation devices (Kay, 1972). In $T$. inodorum the oil sacs are generally less than 1.5 times long as wide (C) and the ribs are much thinner with larger open areas between them (D). The overall shape, width and corona (pappus) morphology is quite variable. Images adapted from Skilbeck et al. (2019). 
Kay (1972) was unaware of T. maritimum subsp. nigriceps since it was first described by Sell \& Murrell (2006); Kay considered the British form to belong to T. maritimum subsp. phaeocephalum found on the coasts of northern Scotland, the Shetland Islands, Faroe islands, Iceland, Greenland, the Arctic coasts of N. America, Scandinavia and the former USSR. Sell \& Murrell (2006) designated 'phaeocephalum' growing in the British Isles, Faeroes and Iceland as the distinct T. maritimum subsp. nigriceps with larger achenes and more triangular phyllaries with very broad darker margins. Stace (2019) commented that $T$. maritimum subsp. nigriceps is often confused with the Arctic T. maritimum subsp. phaeocephalum. The Flora of North America identifies only phaeocephalum as occurring in North America, including both Arctic and subarctic coasts from Alaska to Quebec and Greenland (http://www.efloras.org/object page.aspx?object id=57338\&flora id=1).

\section{The present study and initial findings}

Our study in 2013 and 2019 looked at a total of 40 plants collected from coastal and inland sites in Orkney (see Appendices 1 and 2 for site details) widely distributed across the archipelago, and a single plant from a cereal field in Hampshire, England. The taxa considered were T. maritimum subsp. maritimum, T. maritimum subsp. nigriceps and $T$. inodorum. The characters recorded were as established by Kay (1972) and neatly summarised in Sell \& Murrell (2006). They comprised: shape of oil sacs on achenes; separation of achene ribs; achene size; leaf, whether fleshy or not; phyllary shape; and width and colour of phyllary margin (Table 1).

Table 1. Key identifying characters of the taxa dealt with in this study, as established by Kay (1972) and summarised in Sell \& Murrell (2006)

\begin{tabular}{|l|l|l|l|l|l|l|l|}
\hline & $\begin{array}{l}\text { Oil sac } \\
\text { shape }\end{array}$ & $\begin{array}{l}\text { Separation } \\
\text { of achene } \\
\text { ribs }\end{array}$ & $\begin{array}{l}\text { Achene } \\
\text { length }\end{array}$ & $\begin{array}{l}\text { Fleshy- } \\
\text { leaved }\end{array}$ & $\begin{array}{l}\text { Phyllary } \\
\text { shape }\end{array}$ & $\begin{array}{l}\text { Phyllary } \\
\text { margin } \\
\text { width }\end{array}$ & $\begin{array}{l}\text { Phyllary } \\
\text { margin } \\
\text { colour }\end{array}$ \\
\hline $\begin{array}{l}\text { T. } \\
\text { maritimum } \\
\text { subsp. } \\
\text { maritimum }\end{array}$ & Oblong & $\begin{array}{l}+/- \\
\text { unseparated }\end{array}$ & $\begin{array}{l}c .2-3 \\
\mathrm{~mm}\end{array}$ & $\sqrt{ }$ & $\begin{array}{l}\text { Oblong/broadly } \\
\text { triangular }\end{array}$ & $<0.3 \mathrm{~mm}$ & $\begin{array}{l}\text { Brown/pale } \\
\text { brown }\end{array}$ \\
\hline $\begin{array}{l}\text { T. } \\
\text { maritimum } \\
\text { subsp. } \\
\text { nigriceps }\end{array}$ & Oblong & $\begin{array}{l}+/- \\
\text { unseparated }\end{array}$ & $\begin{array}{l}c .2 .5- \\
3.5 \mathrm{~mm}\end{array}$ & $\sqrt{ }$ & $\begin{array}{l}\text { Broadly } \\
\text { triangular }\end{array}$ & $\begin{array}{l}\text { At least } \\
0.4 \mathrm{~mm}\end{array}$ & $\begin{array}{l}\text { Blackish- } \\
\text { brown }\end{array}$ \\
\hline $\begin{array}{l}\text { T. inodorum } \\
+/- \\
\text { round }\end{array}$ & $\begin{array}{l}\text { Well- } \\
\text { separated }\end{array}$ & $\begin{array}{l}1.5-2.2 \\
\mathrm{~mm}\end{array}$ & $\mathrm{x}$ & $\begin{array}{l}\text { Oblong/narrowly } \\
\text { triangular }\end{array}$ & $<0.3 \mathrm{~mm}$ & Pale brown \\
\hline
\end{tabular}

Observations of the samples were first tabulated using the characters in Table 1. However, as indicated earlier, the combinations of characters in many of the samples of Orkney plants were contradictory for species and subspecies, and especially for those taken from inland habitats. However, by prioritising achene characters and leaving aside subspecies for the moment it was possible to organise the samples into three groups, albeit with varying degrees of confidence, comprising T. maritimum, T. inodorum, and intermediates, as shown in Figs. 4 and 5. Most T. maritimum plants were fairly easily separable, but the remainder had achenes with mixed and conflicting characters. Of the 40 plants, 22 were identified as T. maritimum, two as T. inodorum, and 16 as intermediates. 
The Hampshire plant, collected for comparison, was T. inodorum. It should be noted here that the two Orkney plants identified as T. inodorum on oil sac shape and rib separation possessed some of the suite of vegetative characters for T. maritimum (either subspecies) and T. inodorum in varying combinations; these characters are discussed later in this paper.

Regarding the distribution of the taxa and intermediates in maritime and inland environments in Orkney, of the 15 plants collected on the shore or very close to it, 13 were determined as T. maritimum and two intermediate $T$. maritimum/inodorum, while the 25 inland plants were more varied: 9 of these were determined as T. maritimum, 14 as intermediate $T$. maritimum/inodorum and two as T. inodorum.

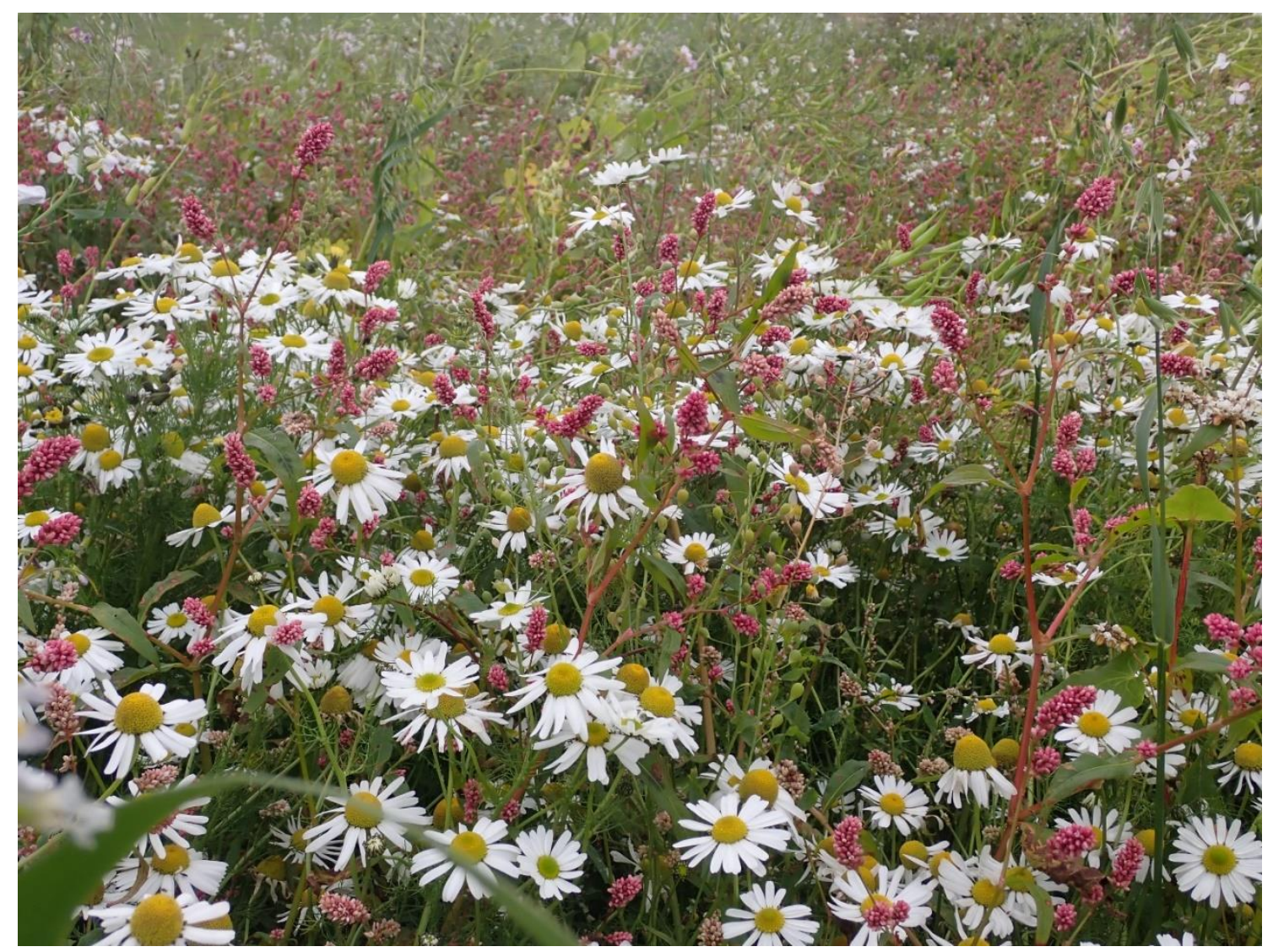

Figure 2. Tripleurospermum growing in a cultivated field at Orally, Orkney Islands, ND459863, September 2020. This site contains mostly T. maritimum with some $T$. inodorum and hybrids between the two. Most of the T. maritimum here have dark broad phyllaries indicative of $T$. maritimum subsp. nigriceps.

\section{Systematic sampling and determination of taxa}

To enable a direct comparison to work by Kay (1972) and in order to help recorders make determinations five mature achenes were sampled from a single capitulum of each specimen and we measured the elongation of the oil-glands and thickness of the ribs (i.e. spacing between them) for each achene, by utilising Kay's semi-quantitative method (Kay, 1972). In this method each achene is matched to a template and rib thickness/separation ('rib development') scored from 1 to 5 , where 5 indicates maximum rib thickness/no 
separation of the ribs and 1 is minimum rib thickness/maximum separation. On this scale a score of 1 to 3 indicates T. inodorum, whilst 5 or 6 indicates T. maritimum. Half scores were allowed where a whole value could not be decided. Similarly, gland elongation was scored from 1 to 9 , with 1 representing the least elongation (slightly wider than long) and 9 the maximum elongation. Again, half scores were allowed and a score of 1 to 3 is taken to indicate T. inodorum, 4 to 9 T. maritimum.

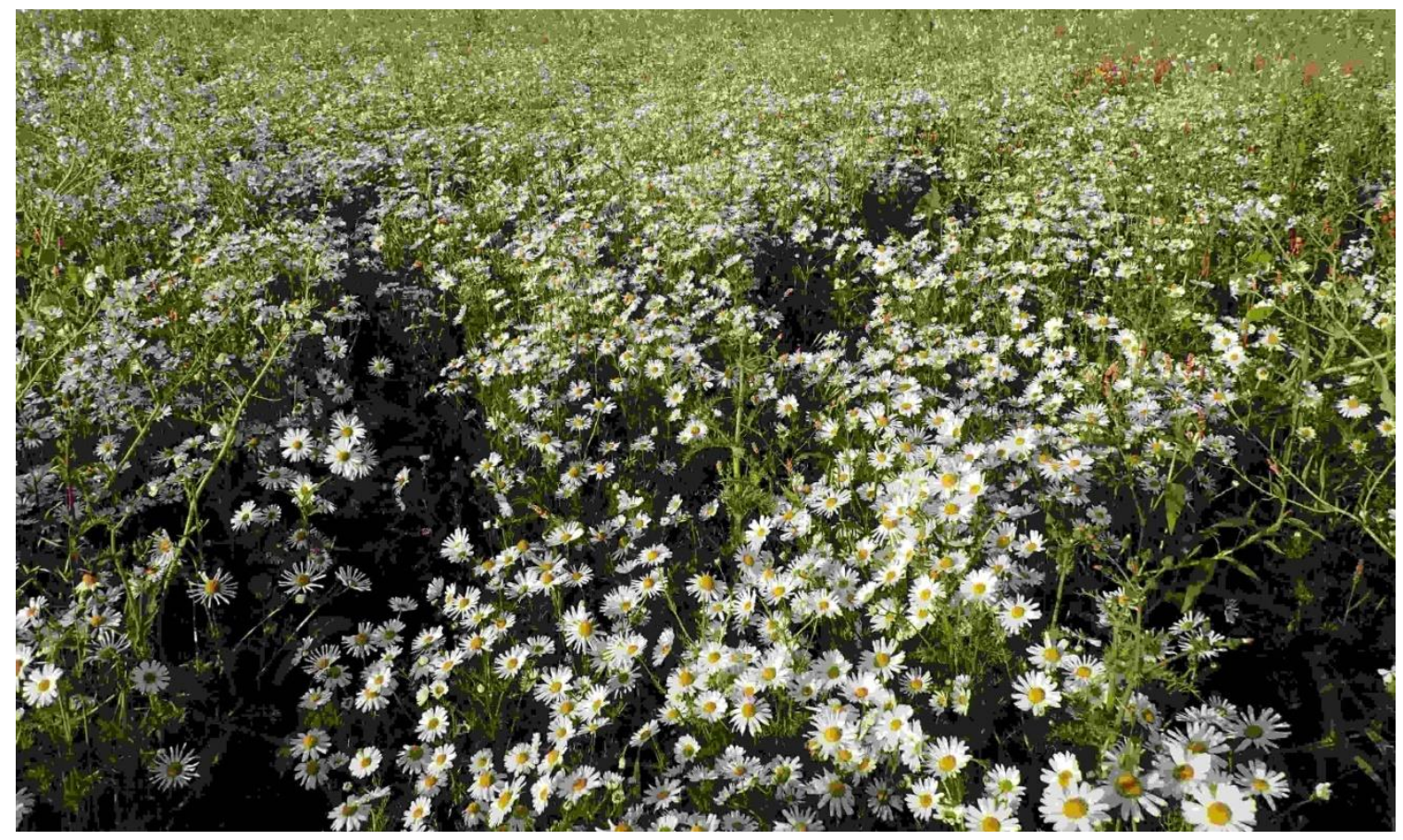

Figure 3. Another view of abundant Tripleurospermum at Orally, Orkney Islands, ND459863, September 2020. Note the marked upright habit at this inland site.

The results are shown in Figs. 4, $5 \& 6$ below. On the basis of gland elongation and rib thickness, most of the population was separated out as T. maritimum and very few as 'pure' $T$. inodorum, but a substantial number had 'intermediate' characteristics, mostly in the form of mixed characters, that is a mismatch between gland shape and rib thickness. Hitherto only a small number of such specimens were noted in a study of the BM specimens (Skilbeck et al., 2019). The proportion of such specimens found here is unparalleled in the collection to date. The specimens labelled as 'hybrids' are our putative hybrids or morphological intermediates and some individuals are more convincingly 'hybrid' than others as we shall discuss. 

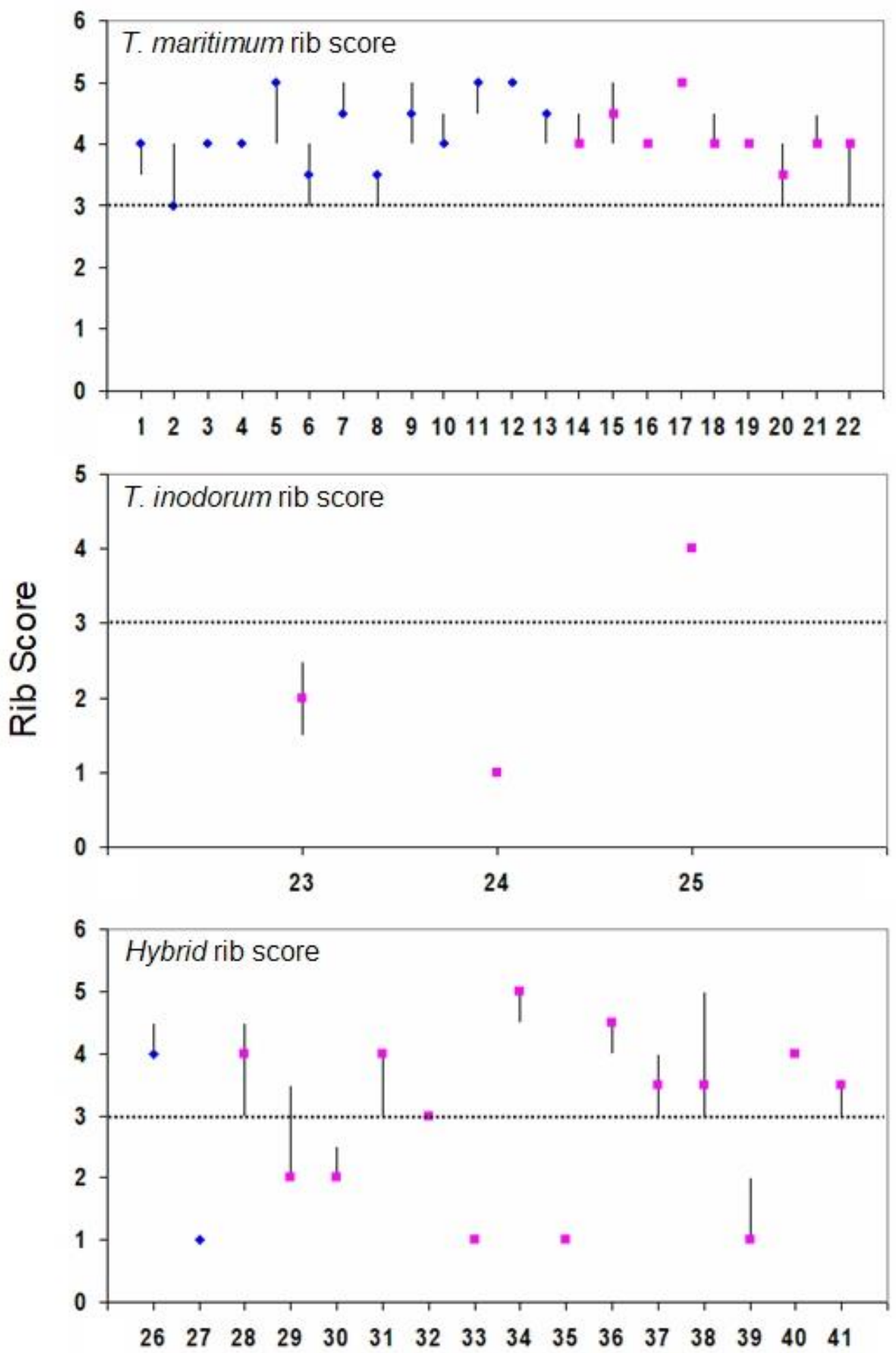

Specimen Number

Figure 4. Rib development scores: median and range from a sample of five achenes. Dotted line indicates cut-off for $T$. maritimum (above the line) and $T$. inodorum (below the line). Blue diamonds indicate coastal specimens; magenta squares inland specimens. 'Hybrid' refers to putative hybrids or morphological intermediates. 

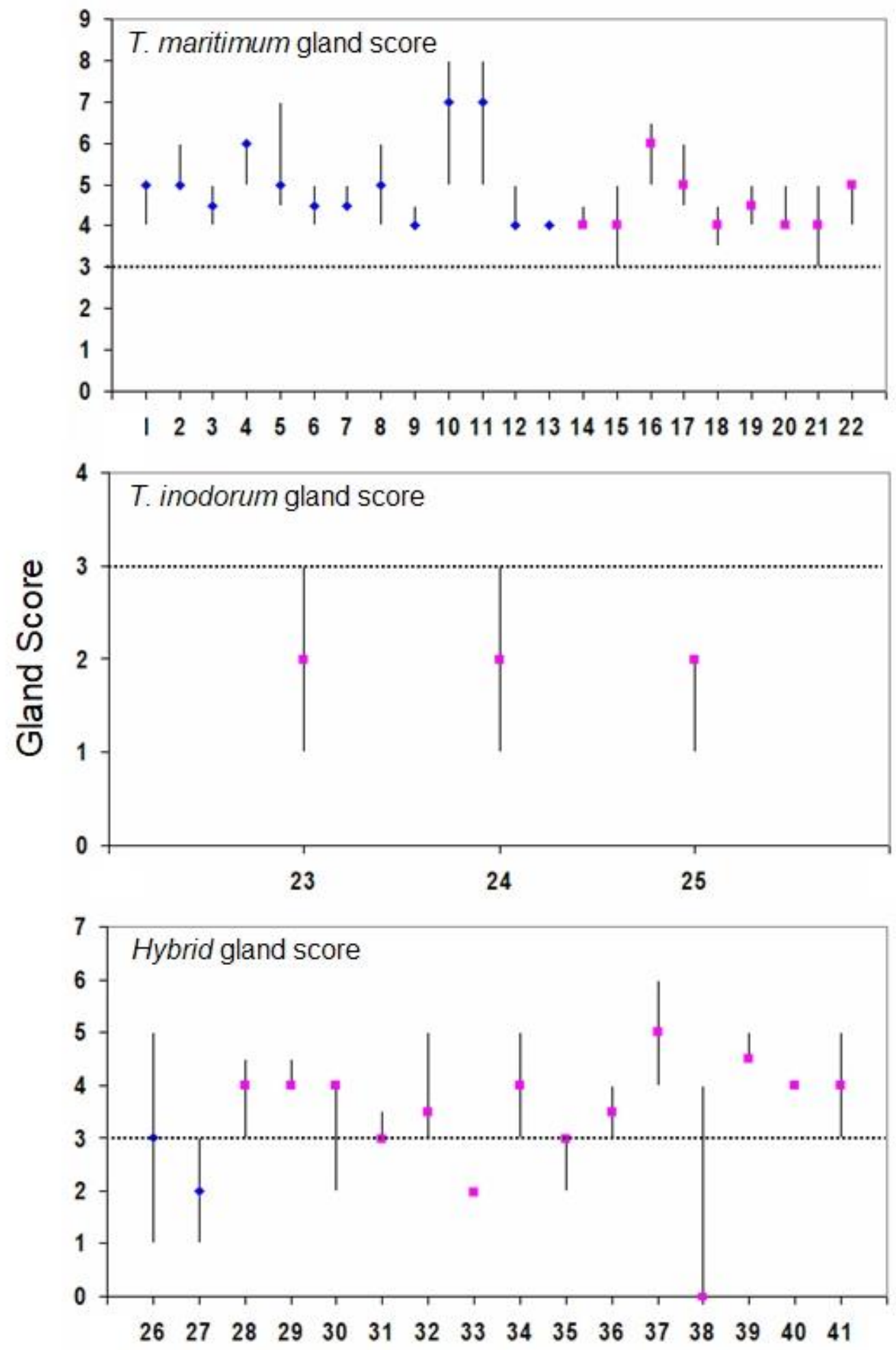

Specimen Number

Figure 5. Gland elongation scores: median and range from a sample of five achenes. Dotted line indicates cut-off for $T$. maritimum (above the line) and $T$. inodorum (below the line). Blue diamonds indicate coastal specimens; magenta squares inland specimens. 'Hybrid' refers to putative hybrids or morphological intermediates. 

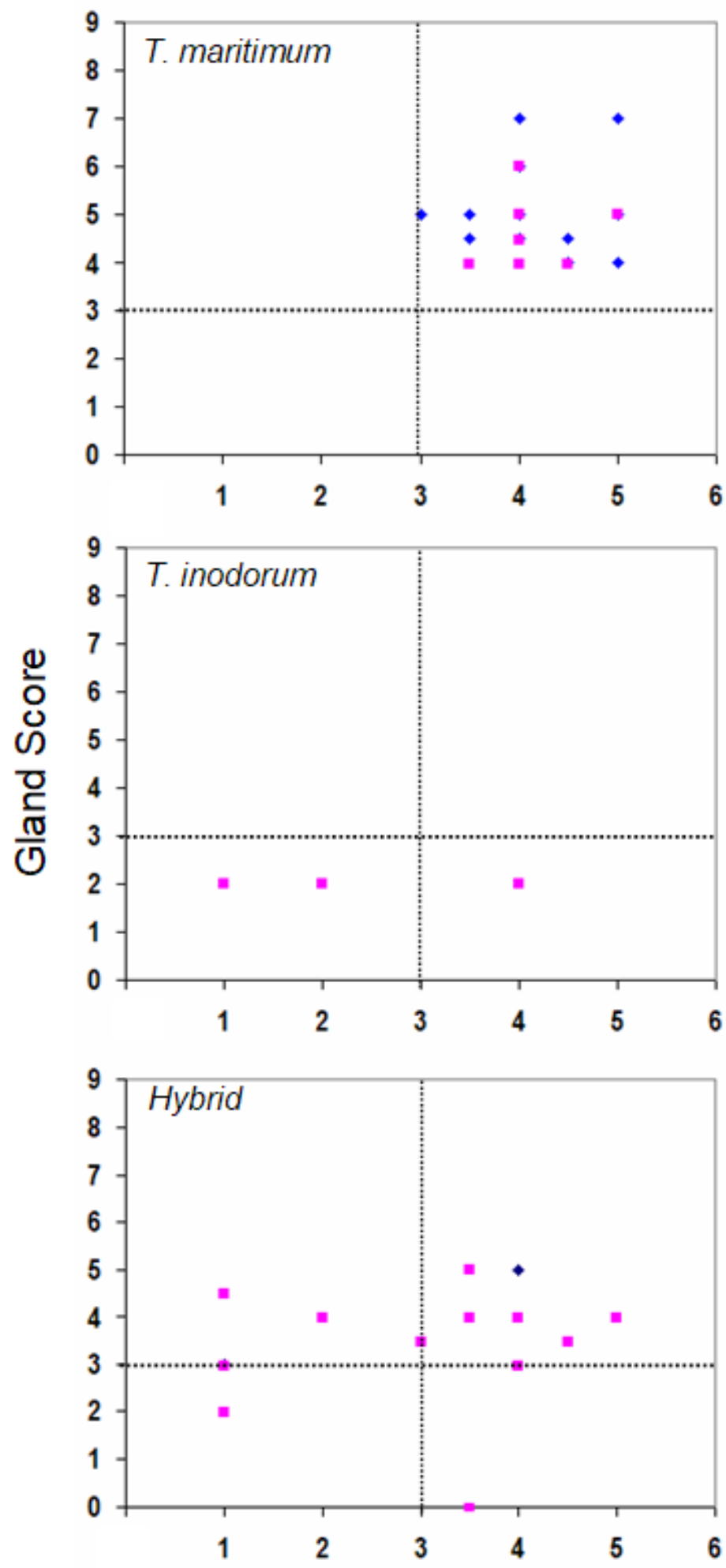

Rib Score

Figure 6. Gland elongation scores plotted against rib development scores: median of five achenes. Dotted lines indicate cut-offs for $T$. maritimum (top right quadrant) and $T$. inodorum (bottom left quadrant). Blue diamonds indicate coastal specimens; magenta squares inland specimens. 'Hybrid' refers to putative hybrids or morphological intermediates. 
Certain individual specimens posed significant dificulties for determination. Specimen 35 of the hybrids, for example, had rib scores consistent with $T$. inodorum and gland scores at the boundary or towards $T$. inodorum based on the sample of 5 achenes. This would suggest $T$. inodorum, however a larger sample revealed a small number of achenes with very elongated ribs (scoring 1 on ribs and 5 on glands) suggesting some introgression and so this specimen was placed with the putative hybrids. In our experience it seems highly unlikely that any achenes of pure $T$. inodorum would have such elongated glands. Where such specimens occur in regions where both parents are nearby, such a trait even in only a small proportion of achenes seems highly suggestive of introgression. As Kay (1972) stated: 'The oil-glands of $T$. inodorum are uniformly isodiametric or broader than long, never longitudinally elongated ...'. We conclude that a sample of five measured achenes was sufficient for reliably determining most specimens, but it is worth quickly scanning over a larger number of achenes.

The case seems less clear-cut with T. maritimum, however. Kay (1972) reported that although oil-gland shape and rib inflation are weakly linked in 'introgressed' populations, much variation exists in oil-gland shape in T. maritimum even when rib inflation is consistently uniform. Of course, introgression can not be entirely ruled out in these cases without a better understanding of how the characters segregate.

Kay (1972) also reported that 'some achenes with isodiametric oil-glands, resembling those of $T$. inodorum, were found among the achenes collected from 'introgressed' beach populations, and some cliff populations, which were morphologically very different from $T$. inodorum in all except achene characters, also had achenes with relatively broad or even isodiametric oil-glands'. Chris Skilbeck confirmed the former observation more recently in a beach population at Tankerton, Kent (v.c.15). Kay (1972) also reported that achenes from some cliff populations, such as those at Port William, Cornwall (v.c.2) and Garvellachs Is., Argyll v.c.98), had less strongly inflated ribs and relatively weakly elongated glands and he concluded that this could have been due to introgression.

We can conclude, then, that a mismatch between rib thickness and gland length is indicative of hybridisation /introgression, though some caution should be exercised in the case of $T$. maritimum in which only the oil-glands are anomolous in populations spatially remote from $T$. inodorum. As far as sampling and scoring five achenes from each specimen is concerned, this technique determined the vast majority of specimens satisfactorily, but it may also pay to scan a larger sample of achenes for anomalies. One might exercise caution when only one parent is found in a region. However Kay (1994) noted that: 'Larger intermediate populations, typically varying around the F1 morphological type but sometimes closer to T. maritimum, are not infrequent in inland ruderal habitats in the maritime areas of western and southern Britain, where they grow on railway ballast, on slag-heaps ..., on waste ground and spray-washed roadsides, and around quarries ... '. For example, our specimen 26 , a putative hybrid, was very maritimum-like with thick ribs, fleshy leaves but some achenes with short oil-glands and was found on a roadside dump. This could be T. maritimum, giving priority to the ribs as suggested by Kay. On the other hand, we can be much more confident that hybrids 29 and 30 are indeed hybrids.

\section{Characteristics of the taxa - vegetative characters}

The habit and leaf morphology of T. maritimum and T. inodorum are variable. However, $T$. maritimum often has prostrate stems, especially when growing on exposed beaches (Fig. 8), but some populations are erect. The Orkney populations were generally erect, especially 
inland (Figs. 2, 3), though plants on strandlines and above exposed shores were often more recumbent. T. inodorum is typically erect (e.g. Fig. 7). The prostrate character may or may not persist in cultivation, for example plants on beaches near Swalecliff are generally prostrate (Fig. 8) but erect in cultivation (Kay, 1972).

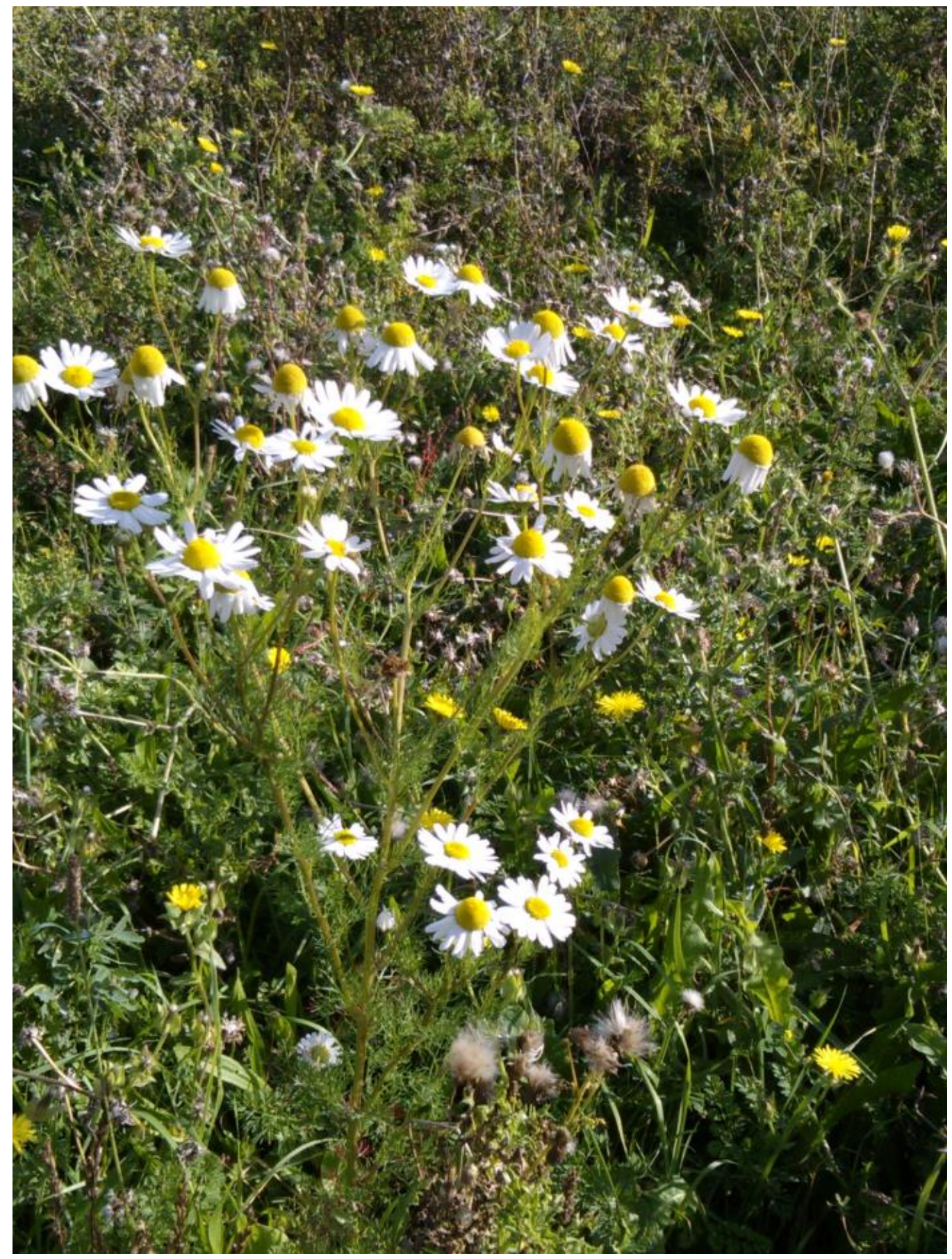

Figure 7. T. inodorum growing on the bank of a pool in Milton Creek Park, v.c.15, TQ913651, October 2018, showing the typical erect habit of this species. (Also available at: https://cronodon.com/images/t-inodorum-2018-6.jpg) 


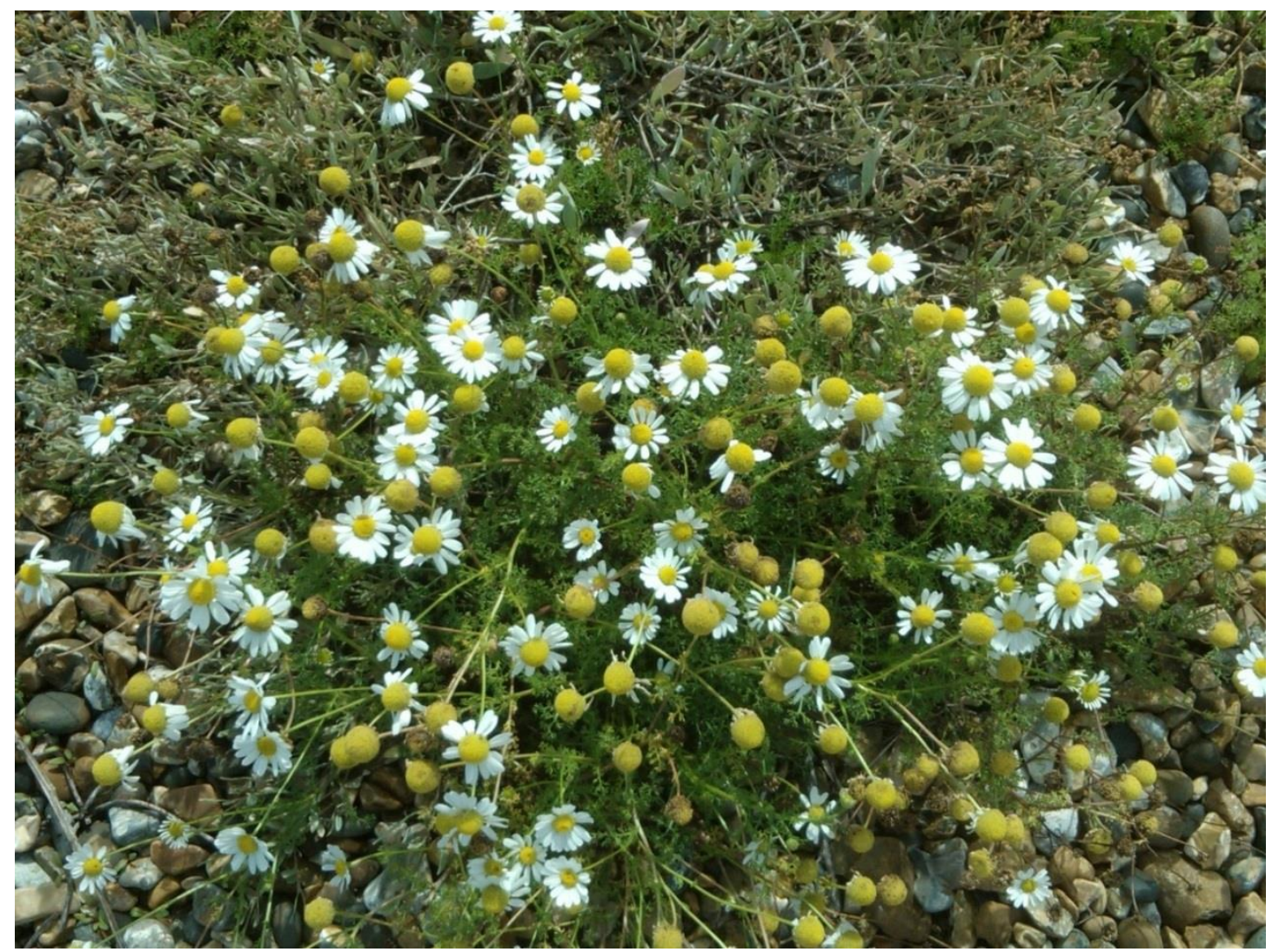

Figure 8. T. maritimum subsp. maritimum, showing the typical prostrate habit found in this population. This photo is also available at: https://www.cronodon.com/images/sea-mayweed-32.jpg

Fleshiness of the leaves and phyllary margin width were also scored. These results are shown in Tables 2 and 3. Fleshiness of leaves was recorded by collectors as 'fleshy' (typical of $T$. maritimum, scored as 2), 'non-fleshy' (typical of $T$. inodorum, scored as 0 ) or 'somewhat fleshy' (intermediate, scored as 1) or 'very fleshy' (scored as 3). The most 'typical' $T$. inodorum was specimen number 23 , which is the only specimen collected for this study outside the Orkney Islands: it was collected from Hampshire, England and has nonfleshy leaves. This specimen is typical of 'classical' $T$. inodorum as found in England. All the Orkney samples had some degree of leaf fleshiness. Fleshiness of leaves in those specimens designated as hybrids is variable and one specimen had unusually fleshy leaves (hybrid specimen 2, Table 2). Fleshiness of leaves is generally a fixed trait with differences remaining in cultivation under similar conditions (Kay, 1972).

Phyllary shape was very variable in the Orkney samples. In order to attempt to resolve the taxonomic significance of phyllary shape, a further 103 inland specimens and 64 coastal specimens of Tripleurospermum were scored using fresh material. Of the 103 inland specimens, 54 were determined as T. maritimum s.l. and of these, 51 had oblong phyllaries, while three had triangular outer phyllaries. A further 10 specimens of $T$. inodorum all had oblong phyllaries, and 39 hybrids also all had oblong phyllaries. All the 64 coastal specimens were determined as T. maritimum and of these, 62 had oblong phyllaries and two triangular phyllaries. Some of the variations in phyllary form are illustrated in Fig. 9. This does not entirely conform with what was expected (see Table 1). Phyllary margin width was used as a primary character to designate individual plants as putative $T$. 
maritimum subsp. nigriceps (Table 3). A more thorough study on phyllary colour and morphology in different populations deserves a separate study.

Table 2. Fleshiness of the leaves of the collected specimens. Fleshiness score: $\mathbf{0}=$ nonfleshy, 1 = slightly fleshy, 2 = fleshy, 3 = very fleshy, as graded on a subjective scale by the collectors. 'Hybrid' refers to putative hybrids or morphological intermediates 


\begin{tabular}{|c|c|c|}
\hline Specimen & Species & Fleshiness of leaves \\
\hline 1 & T. maritimum & 2 \\
\hline 2 & T. maritimum & 2 \\
\hline 3 & T. maritimum & 2 \\
\hline 4 & T. maritimum & 2 \\
\hline 5 & T. maritimum & 2 \\
\hline 6 & T. maritimum & 2 \\
\hline 7 & T. maritimum & 2 \\
\hline 8 & T. maritimum & 2 \\
\hline 9 & T. maritimum & 2 \\
\hline 10 & T. maritimum & 2 \\
\hline 11 & T. maritimum & 2 \\
\hline 12 & T. maritimum & - \\
\hline 13 & T. maritimum & - \\
\hline 14 & T. maritimum & 2 \\
\hline 15 & T. maritimum & 2 \\
\hline 16 & T. maritimum & 2 \\
\hline 17 & T. maritimum & 2 \\
\hline 18 & T. maritimum & - \\
\hline 19 & T. maritimum & 2 \\
\hline 20 & T. maritimum & - \\
\hline 21 & T. maritimum & 2 \\
\hline 22 & T. maritimum & 2 \\
\hline 23 & T. inodorum & 0 \\
\hline 24 & T. inodorum & 2 \\
\hline 25 & T. inodorum & 1 \\
\hline 26 & Hybrid & 2 \\
\hline 27 & Hybrid & 3 \\
\hline 28 & Hybrid & 1 \\
\hline 29 & Hybrid & 2 \\
\hline 30 & Hybrid & 2 \\
\hline 31 & Hybrid & 2 \\
\hline 32 & Hybrid & 2 \\
\hline 33 & Hybrid & 2 \\
\hline 34 & Hybrid & 2 \\
\hline 35 & Hybrid & - \\
\hline 36 & Hybrid & - \\
\hline 37 & Hybrid & 2 \\
\hline 38 & Hybrid & 1 \\
\hline 39 & Hybrid & 1 \\
\hline 40 & Hybrid & 2 \\
\hline 41 & Hybrid & 2 \\
\hline
\end{tabular}



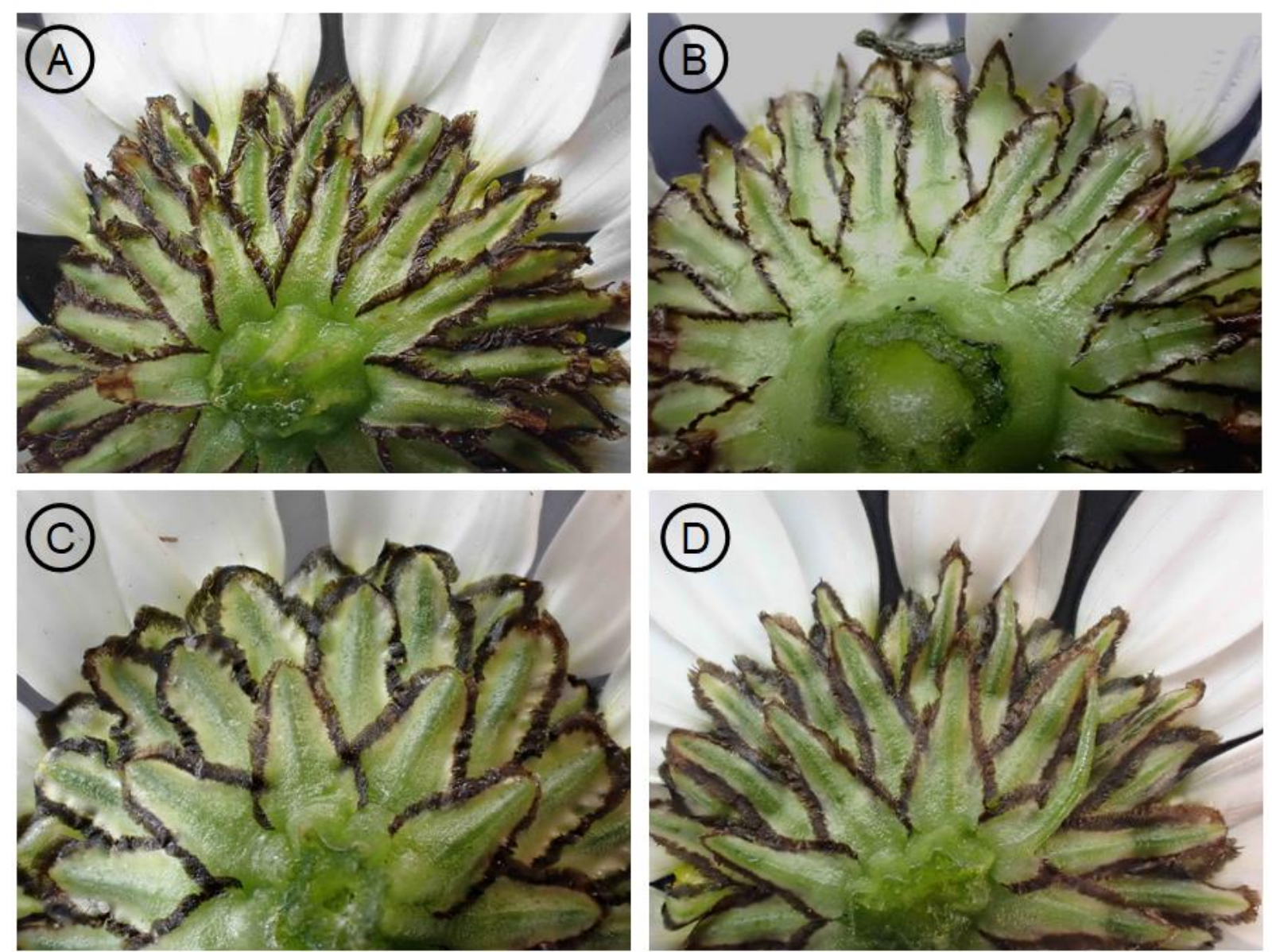

Figure 9. Phyllaries of Orkney specimens. A: The more common form of T, maritimum with phyllaries oblong to narrowly triangular (more triangular than oblong in this case) and broad, blackish margins (Graemeshall, HY490017, October 2020). B: T. maritimum with narrower, dark margins; the margins are often paler in forms with narrow margins

(Burwick, ND440842, October 2020). C: The rarer T. maritimum form with broad triangular phyllary type; even here, the inner phyllaries are oblong (Graemeshall, HY490017, October 2020). D: T. inodorum with borderline-broad, blackish margins (Flaws, ND457856, October 2020).

\section{Subspecies of $T$. maritimum}

Hitherto in this paper we have referred to T. maritimum subsp. maritimum and subsp. nigriceps. But is T. maritimum subsp. nigriceps P.D. Sell distinct from subsp.

phaeocephalum (Ruprecht) Hämet-Ahti.? Sell \& Murrell (2006) designated 'phaeocephalum' growing in the British Isles as the distinct T. maritimum subsp. nigriceps with larger achenes and very broad darker phyllary margins. We have examined descriptions of the two taxa from several sources and it is not clear to us that his separation was fully justified. The dimensions typically given for the phyllary margins of phaeocephalum $(0.4$ to $1 \mathrm{~mm}$ as in the Flora of North America) are identical to those for nigriceps (0.4 mm or more). It should be noted that the holotype of nigriceps designated by Sell is a specimen from Shetland (see https://www.ipni.org/n/77072773-1).

The original description of T. maritimum subsp. nigriceps P. D. Sell is as follows: "Biennial to perennial herb. Stems yellowish-green, sometimes flushed reddish-purple, ascending or erect. Rosette leaves not toothbrush-like, the segments $0.6-1.0 \mathrm{~mm}$ wide, 
fleshy. Capitula $45-60 \mathrm{~mm}$ in diameter. Involucral bracts broadly triangular, with conspicuous blackish-brown, scarious margins at least $0.4 \mathrm{~mm}$ wide. Achenes $2.5-3.5$ $\mathrm{mm}$; ribs on adaxial face contiguous or slightly separated; oil glands more than twice as long as wide. $2 \mathrm{n}=18 . "$

The description for the rosette leaves is identical to that given in Sell \& Murrell (2006) for T. maritimum subsp. maritimum. The key differences are: the 'broadly triangular phyllaries' as opposed to 'oblong or narrowly triangular' with the prominent dark scarious margins; the achenes being somewhat on the large size ( 2.5 to $3.5 \mathrm{~mm}$ as opposed to 2 to $3.0 \mathrm{~mm}$ for subsp. maritimum); the capitulum diameter is at the large end of the spectrum given for subsp. maritimum $(30-45(-60) \mathrm{mm}$ ) and the ascending to erect nature of the stems. We have previously observed large capitulum sizes in northern specimens (Skilbeck et al., 2019).

The description given for ' $T$. phaeocephalum' in the Flora of the USSR (Pobedimova, 1961) is similar: capitula 'large, 30-60 mm in diameter'; 'involucral bracts with triangular green part and wide border, broader than green part of bract, especially at apex, blackishbrown, undulate, entire or discontinuous'; achenes 1-2-3 mm long and stems erect'. The tendency to an erect habit in nigriceps is not typical for T. maritimum: T. maritimum subsp. maritimum tends to have a prostrate habit but some individuals and some populations are erect (Kay, 1972). Moreover, some prostrate individuals give rise to erect offspring in cultivation, whilst in others the prostrate habit persists (Kay, 1972). Furthermore, the prostrate habit is more prevalent in exposed populations (Kay, 1972). In any case, the fact that phaeocephalum and nigriceps are also stated to have an erect habit means that one cannot attribute the erect habit in our northern populations as due to introgression from $T$. inodorum.

Regarding phyllary shape, according to the Flora of North America, T. maritimum subsp. phaeocephalum has broadly triangular phyllaries (with blackish-brown scarious margins 0.4 to $1 \mathrm{~mm}$ wide) whilst T. maritimum subsp. maritimum has oblong to narrowly triangular phyllaries (with scarious margins pale to dark brown). Again, the description for phaeocephalum is identical to that for nigriceps.

This leaves the large achene size of nigriceps as the only possible morphological feature, given in the descriptions, to separate it from phaeocephalum. Achene size in British T. maritimum (s.l.) follows an irregular cline, as recorded by Kay, with increasing size from south to north (Kay, 1972). Kay (1972) also comments that the unusually large achenes of the Shetland populations may be an extension of this cline. T. inodorum also follows a similar cline and Kay (1972) notes that the size of inodorum achenes in north-eastern Scotland is comparable to that of maritimum from the same region, so achene size cannot be used to distinguish them. Given all these observations nigriceps and phaeocephalum seem to be indistinguishable, at least on the morphological level.

It is worth noting that the Flora of the USSR (Pobedimova, 1961) does give some morphological differences between populations of T. maritimum subsp. phaeocephalum in different geographical regions. European specimens, it informs us, have a highly prominent anther tube in some tubular florets in most capitula in full bloom. American specimens have the anthers barely visible or only one-third exserted and the pappus is slightly shorter than in European plants. Siberian specimens have brown, not almost black, phyllaries with a lighter coloured margin. However, the Flora of the USSR concludes that although $T$. maritimum subsp. phaeocephalum is very variable, these variations do not warrant division into separate taxa. 
Table 3. Phyllary characteristics of collected specimens. Specimen number as in table 2. Shape: $\mathbf{O}=$ oblong, $\mathbf{T}=$ triangular; colour of margin: $\mathbf{B}=$ light to medium brown, $\mathbf{D}=$ dark brown to black, PG = pale brown to greenish. The subspecies suggested by phyllary width and colour is indicated. 


\begin{tabular}{|c|c|c|c|c|c|}
\hline Specimen & Species & $\begin{array}{l}\text { Phyllary margin } \\
\text { width }\end{array}$ & $\begin{array}{c}\begin{array}{c}\text { Phyllary } \\
\text { shape }\end{array} \\
\end{array}$ & $\begin{array}{l}\begin{array}{c}\text { Phyllary } \\
\text { colour }\end{array} \\
\end{array}$ & Subspecies \\
\hline 1 & T. maritimum & 0.3 & $\mathrm{O}$ & D & intermediate \\
\hline 2 & T. maritimum & $0.3(0.2-0.4)$ & $\mathrm{O}$ & B & maritimum \\
\hline 3 & T. maritimum & $0.45(0.4-0.5)$ & $\mathrm{O} / \mathrm{T}$ & B & intermediate \\
\hline 4 & T. maritimum & $0.35(0.3-0.4)$ & $\mathrm{O} / \mathrm{T}$ & B & maritimum \\
\hline 5 & T. maritimum & $0.35(0.2-0.5)$ & $\mathrm{T}$ & $\mathrm{D}$ & intermediate \\
\hline 6 & T. maritimum & $0.5(0.4-0.6)$ & $\mathrm{O} / \mathrm{T}$ & D & nigriceps \\
\hline 7 & T. maritimum & $0.6(0.5-0.7)$ & $\mathrm{O} / \mathrm{T}$ & B & intermediate \\
\hline 8 & T. maritimum & $0.4(0.3-0.5)$ & $\mathrm{T}$ & $\mathrm{D}$ & nigriceps \\
\hline 9 & T. maritimum & $0.5(0.4-0.6)$ & $\mathrm{O}$ & D & nigriceps \\
\hline 10 & T. maritimum & $0.6(0.4-0.8)$ & $\mathrm{O}$ & $\mathrm{D}$ & nigriceps \\
\hline 11 & T. maritimum & $0.5(0.4-0.6)$ & $\mathrm{O} / \mathrm{T}$ & D & nigriceps \\
\hline 12 & T. maritimum & - & - & - & - \\
\hline 13 & T. maritimum & - & - & - & - \\
\hline 14 & T. maritimum & $0.5(0.3-0.7)$ & $\mathrm{O}$ & D & nigriceps \\
\hline 15 & T. maritimum & $0.65(0.5-0.8)$ & $\mathrm{T}$ & B & intermediate \\
\hline 16 & T. maritimum & $0.6(0.4-0.8)$ & $\mathrm{O}$ & $\mathrm{D}$ & nigriceps \\
\hline 17 & T. maritimum & $0.5(0.4-0.6)$ & $\mathrm{O}$ & D & nigriceps \\
\hline 18 & T. maritimum & - & - & - & - \\
\hline 19 & T. maritimum & $0.65(0.5-0.8)$ & $\mathrm{O}$ & D & nigriceps \\
\hline 20 & T. maritimum & - & - & - & - \\
\hline 21 & T. maritimum & $0.5(0.4-0.6)$ & $\mathrm{O} / \mathrm{T}$ & D & nigriceps \\
\hline 22 & T. maritimum & $0.7(0.5-0.9)$ & $\mathrm{O} / \mathrm{T}$ & B & intermediate \\
\hline 23 & T. inodorum & $0.15(0.1-0.2)$ & $\mathrm{O}$ & $P G$ & \\
\hline 24 & T. inodorum & $0.7(0.6-0.8)$ & $\mathrm{O}$ & B & \\
\hline 25 & T. inodorum & - & $\mathrm{O}$ & $\mathrm{B}$ & \\
\hline 26 & Hybrid & 0.3 & $\mathrm{O}$ & $\bar{B}$ & $\mathrm{x}$ maritimum \\
\hline 27 & Hybrid & 0.4 & $\mathrm{O} / \mathrm{T}$ & D & $\mathrm{x}$ nigriceps \\
\hline 28 & Hybrid & $0.25(0.2-0.3)$ & 0 & $B$ & $\mathrm{x}$ maritimum \\
\hline 29 & Hybrid & $0.4(0.3-0.5)$ & $\mathrm{O}$ & $\mathrm{D}$ & $\mathrm{x}$ nigriceps \\
\hline 30 & Hybrid & $0.6(0.4-0.8)$ & $\mathrm{T}$ & D & $\mathrm{x}$ nigriceps \\
\hline 31 & Hybrid & $0.45(0.3-0.6)$ & $\mathrm{T}$ & $B$ & $?$ \\
\hline 32 & Hybrid & $0.6(0.5-0.7)$ & $\mathrm{O}$ & B & $?$ \\
\hline 33 & Hybrid & $0.45(0.3-0.6)$ & $\mathrm{O}$ & D & $\mathrm{x}$ nigriceps \\
\hline 34 & Hybrid & $0.4(0.3-0.5)$ & $\mathrm{O} / \mathrm{T}$ & $\mathrm{D}$ & $\mathrm{x}$ nigriceps \\
\hline 35 & Hybrid & - & - & - & - \\
\hline 36 & Hybrid & - & - & - & - \\
\hline 37 & Hybrid & $0.6(0.5-0.7)$ & $\mathrm{T}$ & D & $\mathrm{x}$ nigriceps \\
\hline 38 & Hybrid & 0.3 & $\mathrm{O}$ & B & $\mathrm{x}$ maritimum \\
\hline 39 & Hybrid & $0.6(0.4-0.8)$ & $\mathrm{O} / \mathrm{T}$ & $\mathrm{D}$ & $\mathrm{x}$ nigriceps \\
\hline 40 & Hybrid & $0.6(0.5-0.7)$ & $\mathrm{O} / \mathrm{T}$ & $\mathrm{D}$ & $\mathrm{x}$ nigriceps \\
\hline 41 & Hybrid & $0.5(0.3-0.7)$ & $\mathrm{O}$ & - & - \\
\hline
\end{tabular}

If we accept a geographical separation, i.e. that our subarctic form is nigriceps whilst the Arctic forms in northern Europe are designated phaeocephalum then one wonders what distinction can be made in the North American populations where both subarctic and Arctic zones occur along the mainland coasts where phaeocephalum is found. Consequently, 
without further analysis to compare our populations, with say Scandinavian forms, it seems that no distinction can be maintained and to all intents and purposes we should consider $T$. maritimum subsp. nigriceps and T. maritimum subsp. phaeocephalum to be synonymous. More work is clearly needed to compare the morphology of global populations of Arctic and Subarctic forms and to establish any clines in achene size, etc. Are these two subspecies really distinct at the subspecies level? Do all northern Scottish specimens conform to nigriceps or do they bear similarities to populations of Scandinavian 'phaeocephalum' suggesting introgression? It should be born in mind that the Shetland Islands are considered to be in the subarctic zone. How heterogeneous are these Subarctic / Arctic populations?

A further insight into the variation of T. maritimum can be obtained from Turreson's study of natural populations on the east and west coasts of Sweden (Turreson, 1922). Those on the east coast he reported as perennial halophytes with mostly ascending stems and less fleshy leaves than most west coast plants. The west coast plants were perennial halophytes with thick, short and blunt leaves, more prostrate growth, shorter and broader rays and phyllaries with broad dark margins. Although very variable, the west coast forms had more extreme 'maritime' characteristics.

Regarding the characters noted in Table 1 separating the subspecies of T. maritimum, i.e. subsp. maritimum from what we shall continue to call subsp. nigriceps, as noted earlier we did not find any correlation between these that would neatly distinguish subspecies in the 22 samples. This could be due to hybridisation at the subspecies level, which has been reported before (Hämet-Ahti, 1967). Viewing the characters individually, median achene length per sample was 2.4-3.8 mm, just one of these slightly below the size given for $T$. maritimum subsp. nigriceps and two above that for T. maritimum subsp. maritimum. Colour of phyllary margins was in all Orkney samples shades of brown to dark- or blackish-brown, entirely consistent with nigriceps and partially with maritimum; phyllary shape was scored as oblong or triangular but was a highly variable and difficult character to work with (Table 3). Width of phyllary margin was uneven and also difficult to assess but nevertheless had more potential as a measurable discriminant. In previous work with herbarium specimens (BM herbarium) Skilbeck et al. (2019) encountered similar difficulties (perhaps more so due to specimen shrinkage) with phyllary margins varying considerably in width on the same capitulum. Consequently, a conservative approach was taken in that study: specimens with phyllaries that had visibly strikingly dark and wide margins which were further confirmed by measurement to be $0.4 \mathrm{~mm}$ or greater, and which were more-or-less triangular in contour were determined as T. maritimum subsp. nigriceps. Similarly, we have indicated those specimens which would qualify as putative nigriceps based on the criterion of phyllary margin width and colour (Table 3). Intermediates could be putative products of introgression between subspecies (though we also have possible introgression from $T$. inodorum to consider). Note that phyllary shape was very variable and the taxonomic significance of this remains to be investigated.

\section{Does Tripleurospermum maritimum subsp. phaeocephalum (Rupr.) occur in the British Isles?}

In the past this subspecies has been considered a variety, a form and a separate species and has sometimes been included with subsp. subpolare (Pobed.) Hämet-Ahti (Hämet-Ahti, 
1967). As we have seen, Sell \& Murrell (2006) apparently reclassified British phaeocephalum as T. maritimum subsp. nigriceps with a type from the Shetland Is. This is not entirely without rationale. Hämet-Ahti (1967) considered T. maritimum subsp.

phaeocephalum to be very variable and made-up of different 'races'. The form occuring in Iceland, the Faroe Is., Shetland Is. and Scotland she considered to be one race, American and Asian forms another. The former having a taller habit with longer phyllaries which are narrow and only slightly triangular; the latter with broadly triangular phyllaries with the outermost whorl being shorter than the rest. The situation is further complicated by hybridisation between the various subspecies (Hämet-Ahti, 1967).

The authors have studied the phyllaries in an additional 167 Orkadian Tripleurospermum plants sampled in 2020 and found that of the 84 specimens classified as T. maritimum subsp. nigriceps on the basis of having wide dark scarious phyllary margins, 75 had oblong (or 'slightly triangular') phyllaries. Of the remaining 9, four had distinctly triangular phyllaries and five had variously shaped phyllaries on the same plant. These five specimens were from a total of 19 'nigriceps' specimens collected from Graemeshall. Therefore, it is probable that phyllary morphology varies from population to population.

One $T$. inodorum specimen (specimen 24) was problematic for determination. It had fleshy leaves (scored as 2, Table 2) and wide phyllary margins but its achenes had consistently short glands and its ribs were slightly more inflated than is typical for $T$. inodorum when carefully scored using Kay's system. This specimen could well have some introgression from $T$. maritmum subsp. nigriceps, but its achenes were determined as ' $T$. inodorum with slightly thick ribs' and so it has been placed in the T. inodorum category on the basis of its achenes. It is possible that due to the consistency and intermediate nature of its characteristics that this plant was an $F_{1}$ hybrid, however, it is uncertain how achene characters segregate, but we might expect $F_{2}$ and later generations of hybrids to have more variable segregation of characters. Although there certainly are specimens that one can grade as $T$. inodorum in the Orkney populations, these populations are unusual compared to more southern populations: in general the plants are particularly robust with large achenes. This could be due to the clines already discussed, but it may also suggest that these populations (descended presumably from specimens introduced agriculturally) have a long history of gene flow with both $T$. maritimum subsp. maritimum and, especially, T. maritimum subsp. nigriceps.

\section{Segregation of Characters}

The question arises as to how characters such as achene gland elongation and rib thickness segregate. Turessan (1922) carried out experimental crosses between coastal populations of T. maritimum and inland populations fitting the description of T. inodorum (annual nonsucculent more erect and less bushy annuals) from the Skåne region of Sweden and reported on the vegetative characters of the hybrids. The F1 generation had 'uniformly intermediate' leaves but were erect with one main axis (like inodorum) but with a very bushy crown (like maritimum). In the F2 generation, however, the characters segregated in interesting ways: 28 plants had short and blunt leaves like maritimum, 56 short and pointed leaves, 58 had intermediate leaves ('elongated leaves'), 17 had long segmented leaves (like inodorum) and interestingly 4 had a more extreme 'inodorum' phenotype than the parent with very long and narrow leaves. In terms of leaf thickness, 9 had thicker and more fleshy leaves than the maritimum parent, 62 had thick maritimum-like leaves, 59 were intermediate and 33 had thin inodorum-like leaves. Turessan (1922) also studied the 
leaf histology and noted that in T. maritimum the leaves are isolateral, with well-developed palisade mesophyll all around the periphery whilst in $T$. inodorum the lower palisade was only one cell thick. These data suggest that looking for intermediate leaf characters could tease out the majority of the hybrids, but by no means all.

The way segregation can lead to more extreme characters than either parent is interesting. This suggests that specimens of $T$. maritimum with unusually fleshy leaves may in fact be hybrids. It also raises the question as to whether those specimens lacking oil glands in some or all of their achenes are also hybrids with an extreme trait. For example, most of the achenes sampled from specimen 38 had no oil glands at all. Sometimes glands are hard to see, but in most of the achenes of this specimen none at all were present. The only other specimens where we have seen this was a specimen in BM collected from the Orkney Islands in 1889 and specimens in BM collected from Iceland and Scandinavia. These specimens were designated 'phaeocephalum' by their collectors but are also very variable and have not yet been subjected to rigorous analysis.

\section{Ploidy Considerations}

It should be noted that $T$. inodorum occurs in both diploid $(2 n=18)$ and tetraploid $(2 n=$ 36) forms (sometimes additional or extranumerary chromosomes are also present). The tetraploid cytotype has the advantage of rapid germination, requiring no dormancy (British diploids do) and grows faster, larger and more erect, and with pollen grains about twice the volume. The tetraploid is more erect, but is quite variable and generally indistinguishable from the diploid form in the field. Indeed, the only definitive morphological difference is in the tips of the first true leaves of the seedling which are broad and obtuse in the tetraploid, narrow and acute in the diploid (Kay, 1969).

British populations are diploid. The tetraploid form has not become established in the British Isles but was recorded from Oxfordshire in 1962 (Kay, 1969) and may be a sporadic occurrence, at least in the past as a grain-seed contaminant. Kay (1969) hypothesised that the one recorded tetraploid was attributable to seed imported from Scandinavia. In Fennoscandia (the region encompassing Scandinavia and Finland) the tetraploid form is aggressive and invasive and has been displacing the diploid type (Kay, 1969).

There are differences in ecotype: the diploid prefers upland areas, the tetraploid lowlands. The diploids also prefer wetter and more maritime climates (Kay, 1969). Differences in pollen grain size can also appeal to different pollinators. T. inodorum is chiefly fly pollinated. Possibly relevant here is work done with Heracleum (Apiaceae) which suggests that the compatible $H$. sphondy/ium and $H$. mantegazzianum can co-exist with only limited hybridisation due to fly pollinators showing a preference for different size pollen grains resulting in little cross-pollination (Grace \& Nelson, 1981).

\section{Are Tripleurospermum inodorum and T. maritimum distinct species?}

Tripleurospermum maritimum is diploid and able to hybridise freely with the diploid cytotype of T. inodorum (Kay, 1969). Despite the ease with which the two species hybridise, Kay (1969) perhaps furnished us with the best answer to this question in his consideration of ploidy levels. We summarise some of his key arguments here (See Kay 1969 and references therein).

Diploid inodorum occurs on arable and waste ground and has no natural habitat over most of its range. Natural habitats for the tetraploid form include the 'Solonchak regions' (Russian saltmarshes) of the Lower Volga and mountain slopes of the Caucasus where an 
extreme morph with ray florets either short or absent is found (Kay, 1969). Kay (1969) argues for a scenario in which the diploid form diverged from a common ancestor of both tetraploid T. inodorum and diploid T. maritimum in prehistoric times and suggests that the natural habitat of the diploid T. inodorum may have been water holes where it preferred the trampled soil as this may have predisposed it to colonising disturbed arable soils. As further support for this hypothesis, Kay (1969) cites a study by Dorph-Petersen (1925) in which it was found that the achenes retain $30 \%$ fertility after passage through the bovine digestive tract, implying that this may be akin to its natural mode of dispersion.

This suggests that $T$. inodorum and T. maritimum occupied very different ecosystems in the natural setting and that hybridisation is largely a result of human activity bringing $T$. inodorum to arable fields near the coast. However, Hämet-Ahti (1967) points out that 'ecologically T. maritimum subsp. phaeocephalum is both a seashore and a ruderal plant', which challenges the previous conclusion. Hybridisation readily occurs where the two species meet or come into reasonable proximity. Presently we see no reason to disagree with Kay's conclusion that $T$. inodorum and $T$. maritimum should indeed be classified as separate species. However, as Kay (1969) noted: "... extensive hybridization may occasionally take place when the ecological isolation that normally separates the two species breaks down."

\section{Conclusions}

The Orkney Tripleurospermum populations are considered to contain substantial hybridisation / introgression. The presence of a large number of morphologically intermediate forms supports this conclusion. What does this mean in practice for recording these taxa, especially in the field? First, it will be sensible to record well-marked, apparent T. maritimum growing on the shore as just that, despite the chance of occasional introgression from $T$. inodorum, which is difficult to detect without intensive sampling. Later in the season, the achene characters can be seen well enough with a hand lens to confirm determination (a digital camera can be even better). Inspection of the phyllaries (in the far north at least) will usually indicate which subspecies is involved. Second, it is probable that in some coastal areas plants growing away from the shore are more likely to be to be $T$. maritimum or $T$. maritimum $\times$ T. inodorum intermediates than $T$. inodorum. It will be necessary to examine achenes in a well-formed state from two or three capitula per plant before coming to any conclusion.

Furthermore, it may be less reliable to attempt a determination of every odd specimen than it is to consider whole populations. Where both parents grow in reasonable proximity and appreciable numbers of 'intermediates' can be found then some selected specimens can, we conclude, be recorded as hybrids with as much confidence as morphology can afford. In particular, weakly correlated achene characters (rib inflation and gland length) should be looked for; atypical leaf fleshiness is also an indicator, though most hybrids in the Orkney study had fleshy leaves. In regions where T. maritimum subsp. nigriceps occurs, very wide or thick scarious margins on the phyllaries of ' $T$. inodorum' may indicate introgression with $T$. maritimum subsp. nigriceps but we cannot be conclusive about this as it may be a peculiarity of these far northern population of $T$. inodorum and one should look for inconsistencies in the achenes too. Leaf shape was not examined in detail. Kay (1972) reported T. maritimum as having either fleshy leaves or narrower leaves in a compact brush-like arrangement whilst $T$. inodorum has leaves that are typically less fleshy and 
narrower. However, leaf shape is complex and varies considerably from population to population (Kay, 1972) and would be a study in itself.

Using these methods, it should not take long to work out what the situation is in a particular part of the country. It is likely that what this study has found applies in other islands and exposed coastal places where the influence of the sea is pervasive. There is evidence from Shetland, at least, that apparently mirrors the Orkney situation. In a letter the late Richard Palmer, co-author with Walter Scott of The flowering plants and ferns of the Shetland Islands (1987) to the then vice-county recorder for Orkney in 1979 wrote "... I have paid some attention to cornfield Matricaria in the last year or two on my Shetland visits. Certainly there are slender, clearly annual plants which come close to Matricaria inodora as we get it in the south - though even these plants have the conspicuous dark borders to the phyllaries which most if not all Shetland Matricaria seem to possess (causing it till very recently to be referred to the arctic phaeocephala ${ }^{2}$ ), indeed the dark borders in these cornfield plants are often broader in proportion to the bracts than in the seashore plants. But some, perhaps the majority of the cornfield plants are robust fleshy-leaved things which look very like maritima. Quentin Kay ${ }^{3}$, to whom I sent a batch of material from both cornfields and seashores, thought my cornfield plants intermediate between inodora and phaeocephala...".

An interesting future study might consider the various populations of plants deemed as 'phaeocephalum' in the older literature, both in the British Isles but also in Iceland, the Faroe Is. and Fennoscandia. Our evidence strongly indicates that nigriceps is not distinct from phaeocephalum. Is phaeocephalum morphologically homogeneous? A thorough study of phyllary morphology in different populations would be useful here, along perhaps with a consideration of leaf form and plant habit. Genetic studies could also be useful in assessing the variability within this taxon. How distinct is $T$. inodorum in northern populations? Kay (1969) stated In Britain, I have found that northern Scottish forms of T. inodorum morphologically resembling ... 'phaeocephalum' ... type are connected by a continuous cline of variation to southern English diploids of the typical inodorum type, the latter being morphologically very similar to tetraploid T. inodorum.' To what extent is this morphological cline due to introgression from T. maritimum subsp. nigriceps? By way of conclusion see Table 4 for a summary of the key morphological characteristics of the subspecies of maritimum we have considered.

This paper attempts to derive a way of reliably identifying populations of Tripleurospermum in which hybridisation occurs based on morphology. However, in the ideal world this would be supported by genetic analysis. Comparisons with other Subarctic and Arctic populations would also be fruitful. This may help answer such questions as: Is the tendency of some specimens to lack oil glands altogether a result of trait segregation in hybrids producing an extreme phenotype? Are nigriceps and phaeocephalum distinct taxa? If distinct then how are they distributed?

Finally, a comment about determinations. Stace (2019) rightly pointed out that hybrids between inodorum and maritimum are under-recorded. On morphological grounds it is difficult to be certain of the hybrid status of every individual specimen. To avoid false

\footnotetext{
${ }^{1}$ Tripleurospermum in current taxonomy.

${ }^{2}$ Palmer is writing soon after P. D. Sell designated subsp. nigriceps as a separate taxon from subsp. phaeocephala within Matricaria.

${ }^{3}$ The same Kay referenced earlier who authored the definitive article on Tripleurospermum maritimum (Watsonia, 1972) and before that on T. inodorum (Watsonia, 1969).
} 
positives, it would perhaps be better to carry out a population level study as we have done, to determine where hybridisation is occurring or has occurred. We recommend that if botanists suspect hybridisation that they sample capitula from a number of plants to construct a better picture of what is happening at the population level.

Table 4. A summary of key characteristics of $T$, maritimum from northern populations.

\begin{tabular}{|l|l|l|l|}
\hline & $\begin{array}{l}\text { Tripleurospermum maritimum } \\
\text { s.l. (Orkney; this study) }\end{array}$ & $\begin{array}{l}\text { Subsp. phaeocephalum (N } \\
\text { Norway, NW Russia; Hämet- } \\
\text { Ahit, 1967) }\end{array}$ & $\begin{array}{l}\text { Subsp. maritimum (N Norway, S } \\
\text { Finland; Hämet-Ahit, 1967) }\end{array}$ \\
\hline Length of Stem & $\begin{array}{l}\text { Up to } 60 \mathrm{~cm} \text { in ruderal habitats, } \\
\text { up to } 40 \text { on seashore }\end{array}$ & Up to $40 \mathrm{~cm}$ & Up to $30 \mathrm{~cm}$ \\
\hline Number of flowers & Up to 40 & Up to 10 & Up to 10 \\
\hline Diameter of head & $4-5 \mathrm{~cm}$ & $4-5(-6) \mathrm{cm}$ & $4-5 \mathrm{~cm}$ \\
\hline Length of ray florets & $1.4-2.1 \mathrm{~cm}$ & $1.4-1.6 \mathrm{~cm}$ & $0.8-1.4 \mathrm{~cm}$ \\
\hline Number of ray florets & $25-30$ & $20-35$ & $20-30$ \\
\hline Form of phyllaries & $\begin{array}{l}\text { Variable, outer row oblong or } \\
\text { narrowly triangular, } \\
\text { occasionally broadly triangular, } \\
\text { inner rows oblong; } 1 \\
\text { overlapping outer row and } 4 \\
\text { overlapping inner rows }\end{array}$ & $\begin{array}{l}\text { Broadly triangular, of different } \\
\text { length }\end{array}$ & $\begin{array}{l}\text { Fairly narrow, of different } \\
\text { length }\end{array}$ \\
\hline Scarious margins of phyllaries & $\begin{array}{l}\text { Often very broad (0.2 }-0.9 \\
\text { mm), brown to black }\end{array}$ & $\begin{array}{l}\text { Very broad (up to } 1 \mathrm{~mm} \text { ), } \\
\text { brown to black }\end{array}$ & $\begin{array}{l}\text { Fairly broad (up to } 0.5 \mathrm{~mm} \text { ), } \\
\text { brown }\end{array}$ \\
\hline Length of phyllaries & $6-7 \mathrm{~mm}$ (inner bracts) & $3-6 \mathrm{~mm}$ & $5-6 \mathrm{~mm}$ \\
\hline Width of phyllaries & $2.3-3 \mathrm{~mm}$ (inner bracts) & $3-5 \mathrm{~mm}$ & $1.5-2 \mathrm{~mm}$ \\
\hline Achene & $2.5-3.0 \mathrm{~mm}$ & $?$ & (1.5 - ) $2 \mathrm{~mm}$ \\
\hline Oil glands & Elongated & Elongated \\
\hline
\end{tabular}

Kay (1994) states that hybrids are most likely to be found where arable land with $T$. inodorum occurs within a few metres of $T$. maritimum habitat. However, as noted earlier Kay also reported hybrids further inland in more ruderal habitats; Hämet-Ahti (1967) found maritimum quite far inland (see her Figs. 2 and 3 ) and our study found some maritimum further from coastal habitats (Appendix 1). This increases the potential for hybridisation. Once putative hybrids have been identified, the most likely hybrid candidates could be recorded (along perhaps with a voucher specimen). An additional clue to consider is that F1 hybrids exhibit moderate to high fertility (20 to $80 \%$ ) but this is generally reduced in F2 hybrids and backcrosses and most populations of hybrid plants have a proportion, 5 to $20 \%$, of sterile plants which may have 'abnormal and distorted capitula' (Kay, 1994).

\section{Acknowledgements}

We thank Dr Fred Rumsey and John Hunnex at BM for advice and technical assistance on preparing specimens for addition to the museum British \& Irish Herbarium (BM herbarium). We would also like to thank Dr Fred Rumsey for proofreading the manuscript.

\section{References}

Dorph-Petersen, K. 1925. Examination of the occurrence and vitality of various weed seed species under different conditions. Rep. $4^{\text {th }}$ Int. Seed-testing Congress. Cambridge. Cited in Kay 1965.

Grace, J. \& Nelson, M. 1981. Insects and their pollen loads at a hybrid Heracleum site. New Phytol. 87: 413-423. Available at: https://nph.onlinelibrary.wiley.com/doi/pdfdirect/10.1111/j.1469-8137.1981.tb03212.x 
Kay, Q.O.N. 1969. The origin and distribution of diploid and tetraploid Tripleurospermum inodorum (L.) Schultz Bip. Watsonia 7(3): $130-141$.

Kay, Q.O.N. 1972. Variation in sea mayweed (Tripleurospermum maritimum (L.) Koch) in the British Isles. Watsonia 9: 81-107. Available at: http://archive.bsbi.org.uk/Wats9p81.pdf.

Kay, Q.O.N. 1994. Biological flora of the British Isles: Tripleurospermum inodorum (L.) Schultz Bip. Journal of Ecology 82: 681-697.

Hämet-Ahti, L. 1967. Tripleurospermum (Compositae) in the northern parts of Scandinavia, Finland and Russia. Acta Botanica Fennica 75: 1-19. Available at: https://helda.helsinki.fi/bitstream/handle/10138/36649/299944 075 1967.pdf?sequen $\mathrm{ce}=1$

Pobedimova, E.G. 1961. Tripleurospermum Sch. Bip. In: Komarov, V.L., Flora U.S.S.R. 26: 157-184. Available at: https://www.biodiversitylibrary.org/bibliography/43751\#/summary

Sell, P. \& Murrell, G. 2006. Flora of Great Britain and Ireland. Vol. 4: 556 (486). Cambridge: Cambridge University Press.

Skilbeck, C.A., Lynch, I., Ellenby, M. and Spencer, M.A. 2019. Achene Morphology of British and Irish Mayweeds and Chamomiles: implications for taxonomy and identification. British \& Irish Botany. 1(2): 128-166. Available at: https://doi.org/10.33928/bib.2019.01.128

Stace, C.A., Preston, C.D. \& Pearman, D.A. 2015. Hybrid Flora of the British Isles. London: Botanical Society of Britain and Ireland.

Stace, C.A. 2019. New Flora of the British Isles. $4^{\text {th }}$. ed. Middlewood Green, Suffolk: C \& M Floristics.

Turesson, G. 1922. The genotypical responses on the plant species to the habitat. Hereditas 3: 211 - 350. Available at:

https://onlinelibrary.wiley.com/doi/pdf/10.1111/j.1601-5223.1922.tb02734.x

Copyright retained by author(s). Published by BSBI under the terms of the Creative Commons Attribution 4.0 International Public License.

ISSN: $2632-4970$

https://doi.org/10.33928/bib.2021.03.297 
Appendix 1. Collected specimens determined as T. maritimum. Notes: specimens 1 to 13 are from maritime environments; HWM = above high-water mark. Collectors: JEC = John Crossley; MM = Marion Miller

T. maritimum

\begin{tabular}{|c|c|c|c|c|c|}
\hline Specimen & Location & GR & Date & Collector & Habitat \\
\hline 1 & $\begin{array}{l}\text { Sand of Wright, S. } \\
\text { Ronaldsay }\end{array}$ & ND421936 & $14 / 08 / 2019$ & JEC & $\begin{array}{l}\text { Sand beach on } \\
\text { HWM }\end{array}$ \\
\hline 2 & $\begin{array}{l}\text { Sand of Wright, S. } \\
\text { Ronaldsay }\end{array}$ & ND421936 & $14 / 08 / 2019$ & JEC & $\begin{array}{l}\text { Sand beach on } \\
\text { HWM }\end{array}$ \\
\hline 3 & 4th Barrier, Burray & ND480954 & $27 / 08 / 2019$ & JEC & Sand dune \\
\hline 4 & $\begin{array}{l}\text { Brinian pier, } \\
\text { Rousay }\end{array}$ & HY436275 & 29/08/2019 & JEC & Pier \\
\hline 5 & $\begin{array}{l}\text { Old Head, S. } \\
\text { Ronaldsay }\end{array}$ & ND469857 & $13 / 09 / 2019$ & JEC & Rocky sea shore \\
\hline 6 & $\begin{array}{l}\text { Bay of Suckquoy, } \\
\text { St Andrews }\end{array}$ & HY524040 & 09/09/2013 & JEC & HWM, saltmarsh \\
\hline 7 & $\begin{array}{l}\text { Peedie Sea, } \\
\text { Kirkwall }\end{array}$ & HY445108 & $12 / 09 / 2013$ & JEC & $\begin{array}{l}\text { HWM, brackish } \\
\text { lagoon edge }\end{array}$ \\
\hline 8 & $\begin{array}{l}\text { The Ouse, } \\
\text { Finstown }\end{array}$ & HY361142 & $12 / 09 / 2013$ & JEC & HWM, saltmarsh \\
\hline 9 & $\begin{array}{l}\text { Honeysgoe, S } \\
\text { Ronaldsay }\end{array}$ & ND487933 & $27 / 10 / 2013$ & JEC & $\begin{array}{l}\text { Above shingle } \\
\text { beach }\end{array}$ \\
\hline 10 & 1st Barrier, Holm & HY484013 & $18 / 09 / 2013$ & JEC & $\begin{array}{l}\text { Above HWM, low } \\
\text { soft cliff }\end{array}$ \\
\hline 11 & Saviskaill, Rousay & HY400334 & $27 / 09 / 2013$ & JEC & $\begin{array}{l}\text { Above HWM, storm } \\
\text { boulder beach }\end{array}$ \\
\hline 12 & $\begin{array}{l}\text { Bomasty Bay, } \\
\text { Stronsay }\end{array}$ & HY615235 & Sep-13 & MM & Sand beach \\
\hline 13 & $\begin{array}{l}\text { Bu Sands, } \\
\text { Stronsay }\end{array}$ & HY625241 & Sep-13 & MM & Sand beach \\
\hline 14 & $\begin{array}{l}\text { Pickaquoy Centre, } \\
\text { Kirkwall }\end{array}$ & HY442110 & $12 / 09 / 2013$ & JEC & $\begin{array}{l}\text { Sown wildflower } \\
\text { area }\end{array}$ \\
\hline 15 & $\begin{array}{l}\text { Graemeshall, } \\
\text { Holm }\end{array}$ & HY486019 & $18 / 09 / 2013$ & JEC & $\begin{array}{l}\text { Waste } \\
\text { ground/roadside }\end{array}$ \\
\hline 16 & $\begin{array}{l}\text { North Flaws, S } \\
\text { Ronaldsay }\end{array}$ & ND458856 & $11 / 09 / 2013$ & JEC & Oats crop \\
\hline 17 & $\begin{array}{l}\text { North House, } \\
\text { Tankerness (3) }\end{array}$ & HY492072 & 01/09/2019 & JEC & Arable crop \\
\hline 18 & $2019 \mathrm{C}$ & ND460864 & 03/10/2019 & JEC & $\begin{array}{l}\text { Weedy mixed cereal } \\
\text { crop }\end{array}$ \\
\hline 19 & $\begin{array}{l}\text { North Flaws, S. } \\
\text { Ronaldsay (2) }\end{array}$ & ND457856 & $25 / 08 / 2019$ & JEC & Garden \\
\hline 20 & $\begin{array}{l}\text { Blinkbonny, } \\
\text { Stronsay }\end{array}$ & HY672230 & Sep-13 & MM & $\begin{array}{l}\text { Waste } \\
\text { ground/roadside }\end{array}$ \\
\hline 21 & $\begin{array}{l}\text { Eastdam, S. } \\
\text { Ronaldsay }\end{array}$ & ND445911 & 09/09/2019 & JEC & Earth dump \\
\hline 22 & $\begin{array}{l}\text { North Flaws, S. } \\
\text { Ronaldsay (6) }\end{array}$ & ND457856 & 25/08/2019 & JEC & Waste ground \\
\hline
\end{tabular}


Appendix 2. Specimens determined either as $T$. inodorum or putative $T$. maritimum $\times$. inodorum hybrids. Note: specimens 1 and 2 of the hybrids are from maritime environments. Note that all specimens are from the Orkney Islands except for $T$. inodorum specimen 1, which is typical of more southern $T$. inodorum

T. inodorum

\begin{tabular}{clllll}
\hline Specimen & Location & GR & Date & Collector & Habitat \\
\hline 23 & $\begin{array}{l}\text { Near Hambledon, } \\
\text { Hampshire, } \\
\text { England }\end{array}$ & SU650146 & $22 / 09 / 2019$ & & $\begin{array}{l}\text { Arable - oats } \\
\text { stubble }\end{array}$ \\
\hline 24 & $\begin{array}{l}\text { North House, } \\
\text { Tankerness (2) }\end{array}$ & HY492072 & $01 / 09 / 2019$ & JEC & Arable crop \\
\hline 25 & $\begin{array}{l}\text { Pickaquoy Centre, } \\
\text { Kirkwall }\end{array}$ & HY442110 & $12 / 09 / 2013$ & JEC & $\begin{array}{l}\text { Sown wildflower } \\
\text { area }\end{array}$ \\
\hline
\end{tabular}

T. maritimum $\times$ T. inodorum ?

\begin{tabular}{clllll}
\hline Specimen & Location & GR & Date & Collector & Habitat \\
\hline 26 & $\begin{array}{l}\text { Roadside nr 4th } \\
\text { Barrier, Burray }\end{array}$ & ND479955 & $27 / 08 / 2019$ & JEC & $\begin{array}{l}\text { Rubble and earth } \\
\text { dump by sea }\end{array}$ \\
\hline 27 & $\begin{array}{l}\text { Near Windwick, S } \\
\text { Ronaldsay }\end{array}$ & ND463862 & $18 / 09 / 2013$ & JEC & $\begin{array}{l}\text { above HWM, } \\
\text { crevices in hard cliff }\end{array}$ \\
\hline 28 & $\begin{array}{l}\text { North Flaws, S. } \\
\text { Ronaldsay (3) }\end{array}$ & ND457856 & $25 / 08 / 2019$ & JEC & Garden \\
\hline 29 & $\begin{array}{l}\text { North Flaws, S. } \\
\text { Ronaldsay (4) }\end{array}$ & ND457856 & $25 / 08 / 2019$ & JEC & Garden \\
\hline 30 & Oaklea, St Ola & HY454060 & $06 / 10 / 2013$ & JEC & $\begin{array}{l}\text { Rubbish } \\
\text { tip/roadside }\end{array}$ \\
\hline 31 & Kirkwall (1) & HY443107 & $27 / 08 / 2019$ & JEC & $\begin{array}{l}\text { Neglected suburban } \\
\text { garden }\end{array}$ \\
\hline 32 & Kirkwall (2) & HY443107 & $27 / 08 / 2019$ & JEC & $\begin{array}{l}\text { Neglected suburban } \\
\text { garden }\end{array}$ \\
\hline 33 & $\begin{array}{l}\text { South House, } \\
\text { Tankerness }\end{array}$ & HY498073 & $01 / 09 / 2019$ & JEC & Earth dump \\
\hline 34 & $\begin{array}{l}\text { North House, } \\
\text { Tankerness (1) }\end{array}$ & HY492072 & $01 / 09 / 2019$ & JEC & Arable crop \\
\hline 35 & 2019A & ND460864 & $03 / 10 / 2019$ & JEC & $\begin{array}{l}\text { Weedy mixed } \\
\text { cereal crop }\end{array}$ \\
\hline 36 & 2019B & ND460864 & $03 / 10 / 2019$ & JEC & $\begin{array}{l}\text { Weedy mixed } \\
\text { cereal crop }\end{array}$ \\
\hline 37 & $\begin{array}{l}\text { North Flaws, S. } \\
\text { Ronaldsay }\end{array}$ & ND457854 & $03 / 09 / 2019$ & JEC & Arable crop \\
\hline 38 & $\begin{array}{l}\text { North Flaws, S. } \\
\text { Ronaldsay (1) }\end{array}$ & ND457856 & $25 / 08 / 2019$ & JEC & Garden \\
\hline 39 & $\begin{array}{l}\text { North Flaws, S } \\
\text { Ronaldsay }\end{array}$ & ND456855 & $28 / 09 / 2013$ & JEC & Potato field \\
\hline $\begin{array}{l}\text { North Flaws, S. } \\
\text { Ronaldsay (5) }\end{array}$ & ND457856 & $25 / 08 / 2019$ & JEC & Waste ground \\
\hline Ronaldsay (7) & ND457856 & $25 / 08 / 2019$ & JEC & Waste ground \\
\hline 30 & Norths, & &
\end{tabular}

